Article

\title{
Sorption of Selected Heavy Metals with Different Relative Concentrations in Industrial Effluent on Biochar from Human Faecal Products and Pine-Bark
}

\author{
Koetlisi Andreas Koetlisi * ${ }^{*}$ and Pardon Muchaonyerwa \\ Soil Science Discipline, School of Agricultural, Earth and Environmental Sciences, University of KwaZulu-Natal, \\ Private Bag X01, Scottsville 3209, South Africa; Muchaonyerwa@ukzn.ac.za \\ * Correspondence: koetlisika@gmail.com; Tel.: +(27)-33-260-5764
}

Received: 5 February 2019; Accepted: 22 March 2019; Published: 31 May 2019

check for updates

\begin{abstract}
The removal of heavy metals from effluents at source could reduce contamination of soil and water bodies. A batch sorption experiment was performed to determine the effects of feedstock of biochars pyrolysed at increasing temperature on sorption capacities of $\mathrm{Cu}, \mathrm{Cr}$ and $\mathrm{Zn}$ from industrial effluent and aqueous solutions. Sewage sludge, latrine faecal waste and pine-bark biochars were used. The sorption data were fitted to the Langmuir isotherm. Maximum sorption capacities of latrine waste, sewage sludge and pine-bark biochar $\left(350^{\circ} \mathrm{C}\right)$ were, respectively, 313,400 and $233 \mathrm{mg} \mathrm{kg}^{-1}$ for $\mathrm{Zn}, 102,98.0$ and $33.3 \mathrm{mg} \mathrm{kg}^{-1}$ for $\mathrm{Cu}$, and $18.9,13.8$ and $67.1 \mathrm{mg} \mathrm{kg}^{-1}$ for $\mathrm{Cr}$ from industrial effluent. Conversely, sorption capacities from single metal solutions were 278, 227 and $104 \mathrm{mg} \mathrm{Zn} \mathrm{kg}^{-1}$, 97.1, 137 and $21.3 \mathrm{mg} \mathrm{Cu} \mathrm{kg}^{-1}, 122,106$ and $147 \mathrm{mg} \mathrm{Cr} \mathrm{kg}^{-1}$ on latrine waste, sewage sludge and pine-bark biochar, respectively. Step-wise regression analysis showed that the combined effects of ash, fixed C, $\mathrm{pH}$ influenced $\mathrm{Zn}$ sorption, ash and fixed $\mathrm{C}$ affected $\mathrm{Cu}$ sorption, and $\mathrm{Cr}$ sorption by ash and specific surface area of the biochar. The findings of the study imply that biochar from human faecal waste, particularly sewage sludge, has the potential to be utilized as sorbents of heavy metals from multiple metal effluent and that the sorption is affected by relative concentrations.
\end{abstract}

Keywords: biochar; faeces; heavy metals; pyrolysis; sorption

\section{Introduction}

Environmental contamination with heavy metals poses risks to the biosphere [1,2] and human health [3,4], with the soil-plant-human pathway being a primary mechanism of transfer. Anthropogenic activities such as mining, agriculture and other industrial activities result in elevated levels of heavy metals in soils $[1,5,6]$. For example, industries specializing in electroplating and production of batteries, fertilizers and pesticides produce wastewater, which often contains high concentrations of heavy metals $[1,7,8]$. The discharge of the effluents into sewer systems enriches sewage sludge with the metals, which presents challenges for land disposal of the sludge. The occurrence of multiple heavy metals, from different sources, and their non-biodegradability and persistence in the environment, exacerbate the disposal challenges and pose major ecological risks [9]. Treatment of industrial wastewater, at source, makes it safer for discharge into the environment and reduces environmental pollution $[10,11]$.

Precipitation and complexation are known to be the most effective strategies in removal of metals from effluents but the requirement of specialized reagents and expensive equipment makes them too expensive $[7,12,13]$. Other available technologies for treatment of wastewater, including membrane filtration, ozonation, advanced oxidation and adsorption, have also shown high effectiveness $[10,11,14]$, but the high costs also limit their application. Biochar has shown potential to be a cost-effective biosorbent for the removal of toxic metals from aqueous solutions and wastewater $[6,13,15-17]$. The 
effectiveness depends on biochar characteristics owing to properties of the feedstock and pyrolysis conditions [18-21].

Studies by [22-24] have shown the capacity of different biochar types to remove heavy metals such as $\mathrm{Cd}, \mathrm{Cu}$ and $\mathrm{Zn}$ from aqueous solution. Biochar types from nut shells, plum stones, wheat straws and grape stalks and husks were highly effective in removal of $\mathrm{Cd}$ from aqueous solution, with wheat straw and grape husk and stalks being the most efficient [19]. Biochar produced at higher pyrolysis temperature has been shown to increase $\mathrm{Cd}$ sorption capacity due to higher aromatic structure, $\mathrm{pH}$ and surface area $[15,25]$. It is essential to note that most of the studies on the removal of metals by biochar were done with single metals $[23,24]$ with fewer on mixtures of metals, at equal concentrations, in aqueous solutions. There is evidence that presence of competing metals in aqueous solution affect the sorption of individual metals. For example, the adsorption capacities of metals from aqueous solution onto sesame straw biochar were in the order of $\mathrm{Pb}>\mathrm{Cd}>\mathrm{Cr}>\mathrm{Cu}>\mathrm{Zn}$ from single-metal and $\mathrm{Pb}>\mathrm{Cu}>\mathrm{Cr}>\mathrm{Zn}>\mathrm{Cd}$ multi-metal solutions [26]. Where multiple metals were used, the mixtures were often prepared with equal concentrations [26]. However, in reality, the metals occur at different concentrations in industrial effluents, and the concentration effects may affect the preferential uptake of metals by sorbents.

In a study on sorption and desorption of heavy metal on biochar and commercial activated carbon, [27] reported that various operating factors such as adsorbent dose and initial concentration are influential on the sorption. In that study, sorption capacity increased with increase in initial concentration of metal ions [27]. There is need to understand the potential of using different types of biochar from locally available feedstocks on removal of multiple metals from a typical industrial effluent.

Biochar from human faecal wastes [28] differed in their physicochemical properties, with higher cadmium (Cd) sorption capacity, compared to those from pine-bark [29]. The Cd sorption generally declined with increase in pyrolysis temperature $\left(350-650^{\circ} \mathrm{C}\right)$ from 200 to 167 for latrine waste biochar, and from 143 to $36 \mathrm{mg} \mathrm{kg}^{-1}$ for sewage sludge biochar [28], while it slightly increased from 20 to $34 \mathrm{mg} \mathrm{kg}^{-1}$ for pine-bark biochar [29]. Whereas ash content and phosphorus composition explained the sorption of $\mathrm{Cd}$ on faecal biochar, fixed $\mathrm{C}, \mathrm{pH}$ and Brunauer-Emmett-Teller (BET) surface area appeared to be more important in pine-bark biochars. The potential of these biochar types to remove mixtures of heavy metals from industrial effluents needs to be understood. Therefore, the objective of this study was to determine effects of biochar types from human faecal waste and pine-bark on sorption of multiple metals from industrial effluent and single metal aqueous solutions.

\section{Results}

\subsection{Sorption of Zn from Multiple Metal Effluent and Single Metal Solutions}

Based on the shape of the sorption isotherms, biochar from pine-bark had lower affinity for $\mathrm{Zn}$ than those from latrine waste and sewage sludge pyrolysed at $350{ }^{\circ} \mathrm{C}$, both when the multi-metal effluent (Figure 1a) and single metal solution (Figure 1b) were used. Sorption maxima of Zn was higher on latrine waste and sewage sludge than pine-bark biochar, both for multiple metal effluent and single metal solution (Figure $2 \mathrm{a}, \mathrm{b}$ ). The sorption maximum values for all biochar types were lower for single metal solutions than multiple metal effluent. Biochar from latrine waste and sewage sludge pyrolysed at 550 and $650^{\circ} \mathrm{C}$ exhibited lower affinity for $\mathrm{Zn}$ from multi-metal effluent than the same feedstocks pyrolysed at $350{ }^{\circ} \mathrm{C}$. Pyrolysis at $650{ }^{\circ} \mathrm{C}$ resulted in lower $\mathrm{Zn}$ affinity for latrine waste biochar and higher affinity for sewage sludge biochar than biochar pyrolysed at $550{ }^{\circ} \mathrm{C}$ (Figure 1c). The maximum sorption of $\mathrm{Zn}$ on latrine waste biochar declined from 312.5 to $192.3 \mathrm{mg} \mathrm{kg}^{-1}$ with increasing pyrolysis temperature from 350 to $550{ }^{\circ} \mathrm{C}$, with no further change at $650{ }^{\circ} \mathrm{C}$ (Figure $2 \mathrm{~b}$ ). Increasing pyrolysis temperature did affect $\mathrm{Zn}$ sorption on sewage sludge biochar. The constant related to bonding energy was higher on pine-bark than faecal biochar and was also higher for single metal solutions than the effluent (except latrine waste) (Table 1). While maximum sorption values were similar between latrine waste and sewage sludge biochar, the bonding energy was higher for sewage 
sludge biochar. Coefficients of variation for faecal biochar types $\left(350^{\circ} \mathrm{C}\right)$ were $>0.90$ and was 0.68 for pine-bark biochar from multiple metal effluent. However, constants related to bonding energy declined with increase in pyrolysis temperature for both latrine waste and sewage sludge biochar. Coefficients of variation were lower than 0.90 for at the $550{ }^{\circ} \mathrm{C}$ pyrolysis temperature, for both latrine waste and sewage sludge biochar.
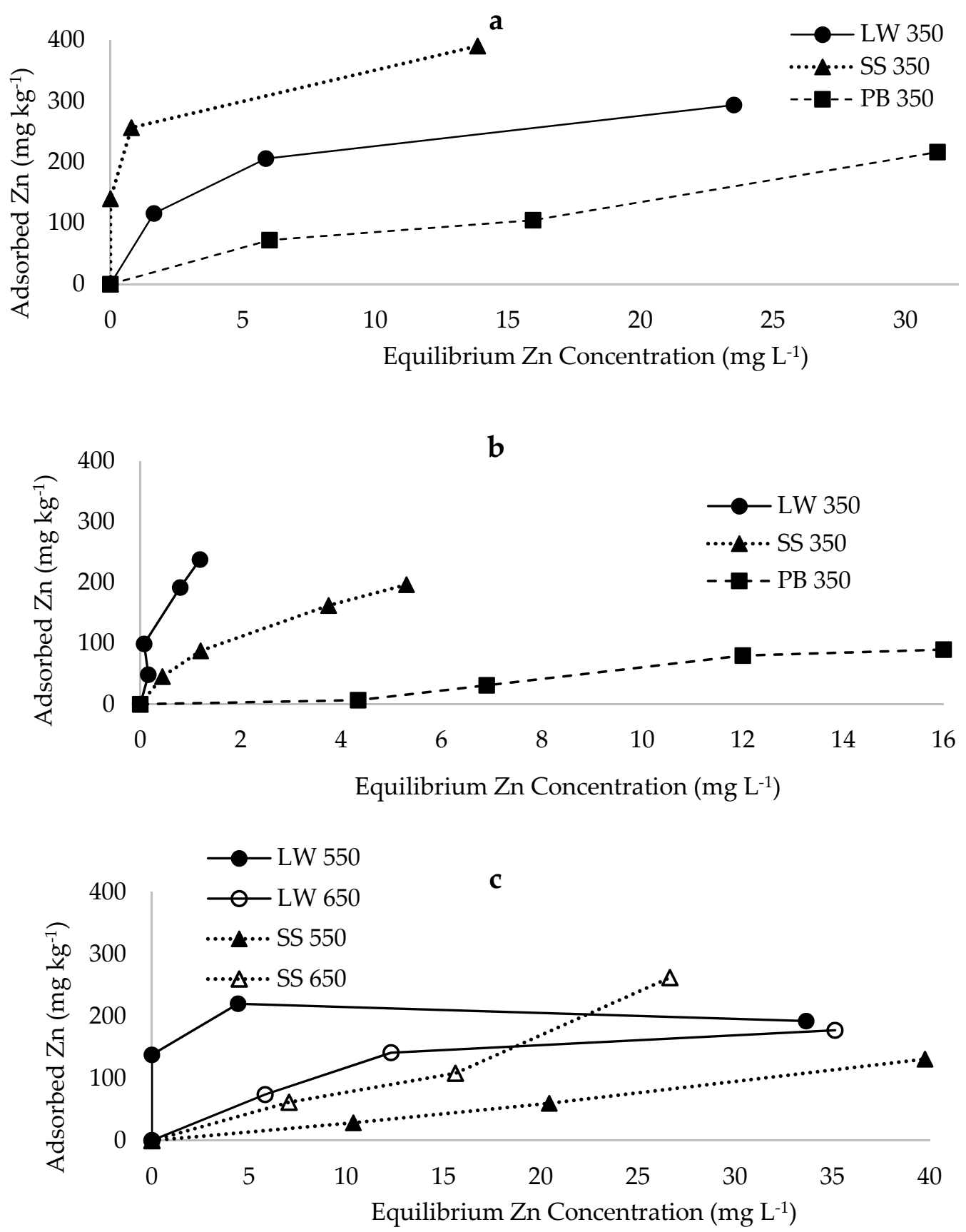

Figure 1. Sorption isotherms of zinc: (a) from effluent on biochar pyrolysed at $350{ }^{\circ} \mathrm{C}$, (b) single metal on biochar pyrolysed at $350{ }^{\circ} \mathrm{C}$ and (c) from effluent on biochar pyrolysed at 550 and $650{ }^{\circ} \mathrm{C}$. $\mathrm{LW}=$ latrine waste biochar, $\mathrm{SS}=$ sewage sludge biochar, $\mathrm{PB}=$ pine-bark biochar. 


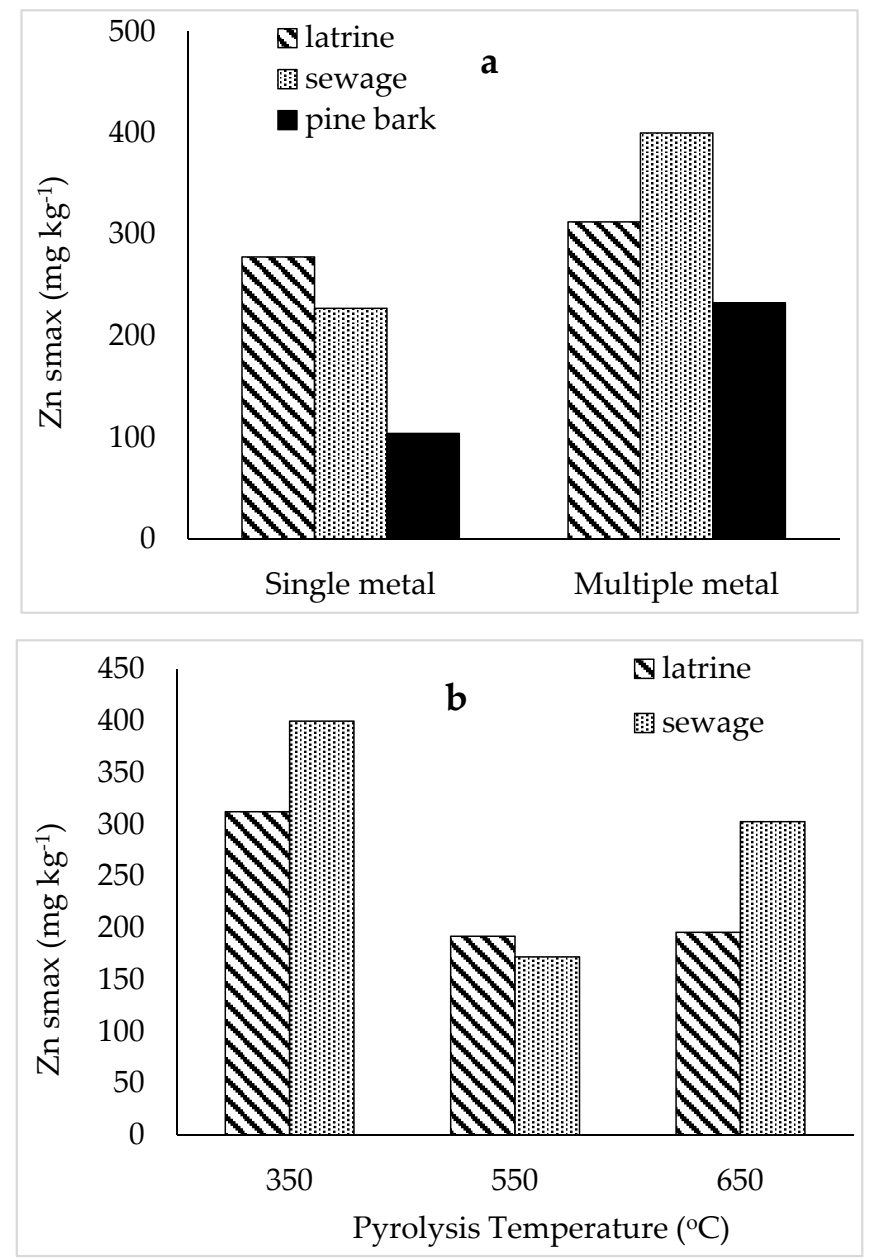

Figure 2. Maximum zinc sorption on faecal and pine-bark biochar pyrolysed at $350{ }^{\circ} \mathrm{C}(\mathbf{a})$ and on faecal biochar at increasing pyrolysis temperatures $(\mathbf{b})$.

Table 1. The $b\left(\mathrm{~L} \mathrm{~kg}^{-1}\right)$ and $r^{2}$ values of linearized Langmuir models of zinc on biochars from latrine waste, sewage sludge and pine bark.

\begin{tabular}{ccccc}
\hline \multirow{2}{*}{ Biochar } & \multicolumn{4}{c}{$\boldsymbol{b}$-Value and $\boldsymbol{r}^{\mathbf{2}}$} \\
\cline { 2 - 5 } & \multicolumn{2}{c}{ Source of Metals $\mathbf{( 3 5 \mathbf { 5 0 } ^ { \circ } \mathbf { C } \text { Pyrolysis) }}$} & Pyrolysis Temperature (Metals from Effluent) \\
\cline { 2 - 5 } & Aqueous Solution & Effluent & $\mathbf{5 5 0}^{\circ} \mathbf{C}$ & $\mathbf{6 5 0}^{\circ} \mathbf{C}$ \\
\hline Latrine waste & $3.6(0.77)$ & $0.55(0.98)$ & $-3.71(1.00)$ & $0.22(0.94)$ \\
Sewage sludge & $0.86(0.90)$ & $5.00(1.00)$ & $0.04(0.34)$ & $0.07(0.38)$ \\
Pine-bark & $0.18(0.48)$ & $0.11(0.68)$ & - & - \\
\hline
\end{tabular}

\subsection{Sorption of $\mathrm{Cu}$ from Multiple Metal Effluent and Single Metal Solutions}

Similarly to $\mathrm{Zn}$, the shape of the sorption isotherms shows that pine-bark biochar had lower affinity for $\mathrm{Cu}$ than those from latrine waste and sewage sludge pyrolysed at $350{ }^{\circ} \mathrm{C}$, both for the effluent (Figure 3a) and single metal solution (Figure 3b). Affinity for $\mathrm{Cu}$ from single metal solution was higher for latrine waste biochar than sewage sludge biochar, while for the effluent sewage sludge biochar had greater affinity. The sorption maxima of $\mathrm{Cu}$ from single metal solution was higher for latrine waste and sewage sludge biochar and lower for pine-bark biochar when compared with those of multi-metal effluent (Figure 4a). Also similar to $\mathrm{Zn}$, maximum sorption of $\mathrm{Cu}$ was higher for biochar from latrine waste and sewage sludge than pine-bark biochar, both for the effluent and single metal solution. Sorption of $\mathrm{Cu}$ from multi-metal effluent was lower on latrine waste biochar than sewage sludge, while for single metal solution, sorption on latrine waste biochar was higher $\left(149.6 \mathrm{mg} \mathrm{kg}^{-1}\right)$ 
than on sewage sludge ( $\left.128.4 \mathrm{mg} \mathrm{kg}^{-1}\right)$. Also similar to $\mathrm{Zn}$, the constant related to bonding energy was higher for single metal solutions than the effluent, except pine-bark biochar (Table 2). Latrine waste biochar had the highest bonding energy constant while pine-bark biochar had the lowest. All coefficients of variation were $>0.95$, except for $\mathrm{Cu}$ sorption on latrine waste biochar from single metal solution.

Maximum sorption of $\mathrm{Cu}$ from effluent decreased with increasing pyrolysis temperature for the faecal biochar types, with $128 \mathrm{mg} \mathrm{kg}^{-1}$ at $350{ }^{\circ} \mathrm{C}$ and $40.3 \mathrm{mg} \mathrm{kg}^{-1}$ at $650{ }^{\circ} \mathrm{C}$ sewage sludge biochar (Figure 4b). On latrine waste biochar, $\mathrm{Cu}$ sorption also decreased with increasing pyrolysis temperature from $150 \mathrm{mg} \mathrm{kg}^{-1}$ at $350{ }^{\circ} \mathrm{C}$ to $72.9 \mathrm{mg} \mathrm{kg}^{-1}$ at $650{ }^{\circ} \mathrm{C}$. The $b$-values also decreased with increase in pyrolysis temperature (Table 2). The only coefficients of variation that were $<0.9$ were those on biochar produced at $650^{\circ} \mathrm{C}$. Pine-bark 550 and $650^{\circ} \mathrm{C}$ were not tested for metal sorption following their low metal sorption affinities at $350^{\circ} \mathrm{C}$.
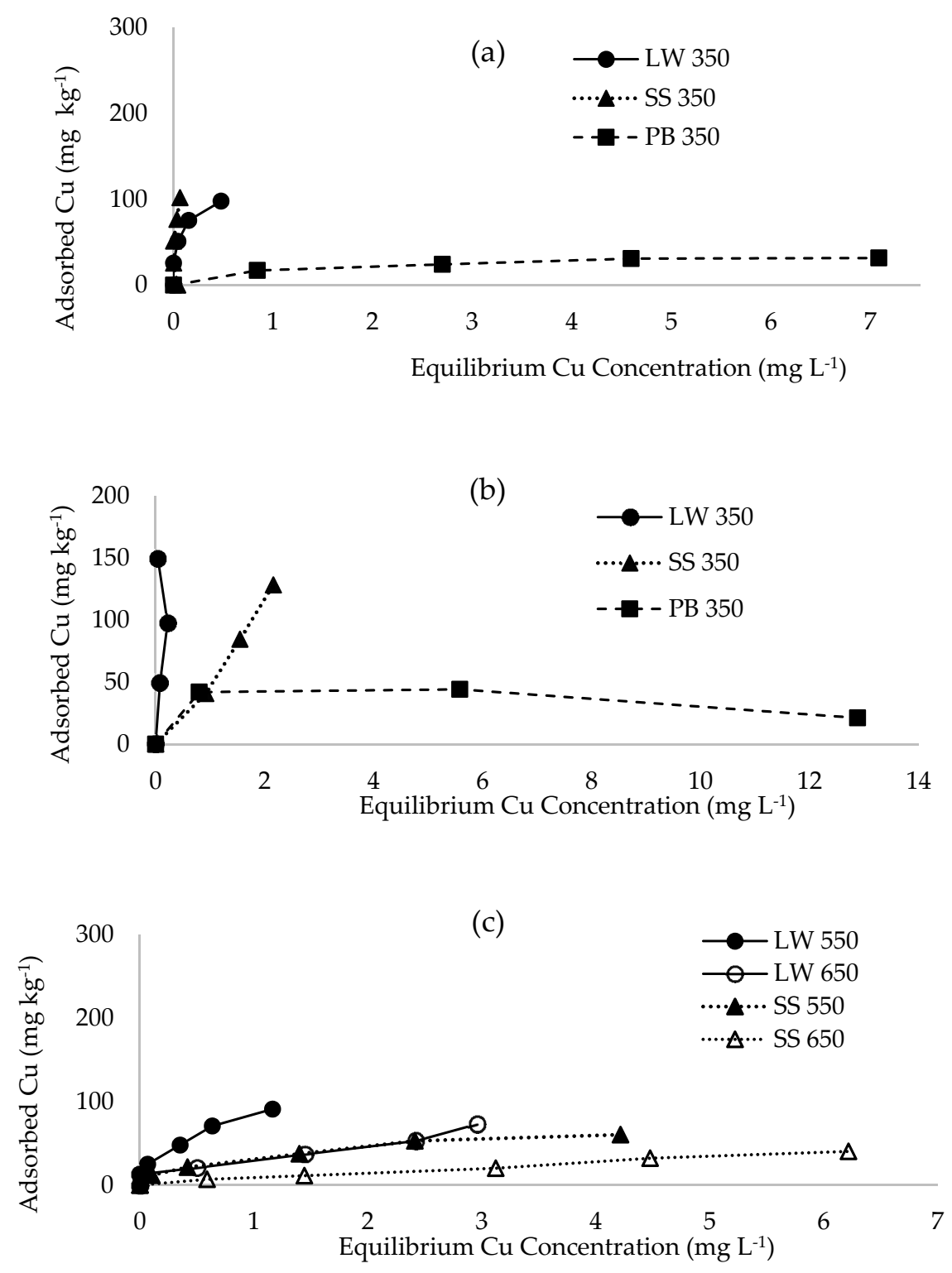

Figure 3. Sorption isotherms of copper from: (a) effluent on biochar pyrolysed at $350^{\circ} \mathrm{C},(\mathbf{b})$ single metal on biochar pyrolysed at $350{ }^{\circ} \mathrm{C}$ and (c) effluent on biochar pyrolysed at 550 and $650{ }^{\circ} \mathrm{C}$. $\mathrm{LW}=$ latrine waste biochar, $\mathrm{SS}=$ sewage sludge biochar, $\mathrm{PB}=$ pine-bark biochar. 

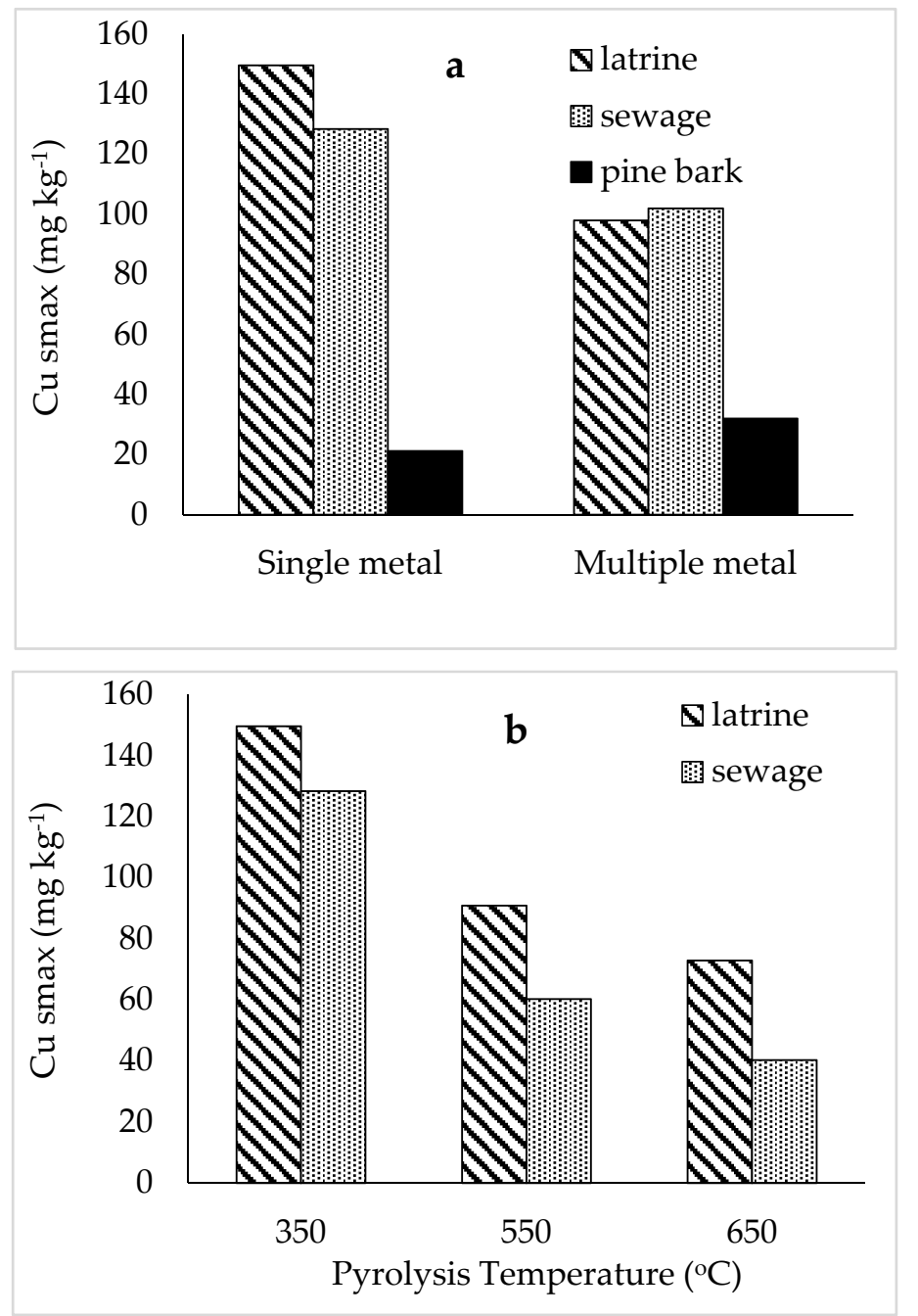

Figure 4. Maximum copper sorption on faecal and pine-bark biochar pyrolysed at $350{ }^{\circ} \mathrm{C}(\mathbf{a})$ and on faecal biochar at increasing pyrolysis temperatures (b).

Table 2. The $b\left(\mathrm{~L} \mathrm{~kg}^{-1}\right)$ and $r^{2}$ values of linearized Langmuir models of copper on biochars from latrine waste, sewage sludge and pine bark.

\begin{tabular}{|c|c|c|c|c|}
\hline \multirow{3}{*}{ Biochar } & \multicolumn{4}{|c|}{$b$-Value and $r^{2}$} \\
\hline & \multicolumn{2}{|c|}{ Source of Metals $\left(350^{\circ} \mathrm{C}\right.$ Pyrolysis) } & \multicolumn{2}{|c|}{ Pyrolysis Temperature (Metals from Effluent) } \\
\hline & Aqueous Solution & Effluent & $550{ }^{\circ} \mathrm{C}$ & $650^{\circ} \mathrm{C}$ \\
\hline Latrine waste & $51.5(0.84)$ & 32.7 (0.99) & $5.67(0.92)$ & $1.15(0.75)$ \\
\hline Sewage sludge & $1.22(0.46)$ & $510(0.97)$ & $1.82(0.95)$ & $0.32(0.58)$ \\
\hline Pine-bark & $-1.25(0.95)$ & $1.97(0.98)$ & - & - \\
\hline
\end{tabular}

\subsection{Sorption of Cr from Multiple Metal Effluent and Single Metal Solutions by Biochar}

The adsorption isotherms for $\mathrm{Cr}$ on latrine waste, sewage sludge and pine-bark biochar types are shown in Figure 5. The isotherms fitted well in the Langmuir model. The maximum sorption of $\mathrm{Cr}$ was higher (at least eight times) for single metal solutions than multiple metal effluent for all biochars (Figure 6). Sorption maxima of $\mathrm{Cr}$ were in the order pine-bark $>$ latrine waste $>$ sewage sludge, both for single metal and multiple metal effluent solutions. The constant related to bonding energy was lower for single metal solutions than the effluent for all biochar types pyrolysed at $350{ }^{\circ} \mathrm{C}$. The coefficient of bonding energy was highest for pine-bark followed by latrine waste. On pine bark biochar pyrolysed at 550 and $650{ }^{\circ} \mathrm{C}$, the isotherms suggest that all the $\mathrm{Cr}$ was removed (sorbed), 
leaving no $\mathrm{Cr}$ in solution, as such a sorption maximum could not be calculated because of lack of fit to the Langmuir isotherm (Figure 5c). On sewage sludge, $\mathrm{Cr}$ sorption declined with increase in pyrolysis temperature, with the highest bonding energy coefficient $\left(79 \mathrm{~L} \mathrm{~kg}^{-1}\right)$ for the $350{ }^{\circ} \mathrm{C}$ biochar, and lower $\left(1.0 \mathrm{~L} \mathrm{~kg}^{-1}\right)$ for higher temperatures. Again, $\mathrm{Cr}$ sorption by latrine waste at $350{ }^{\circ} \mathrm{C}$ from the effluent did not fit Langmuir model (Table 3).

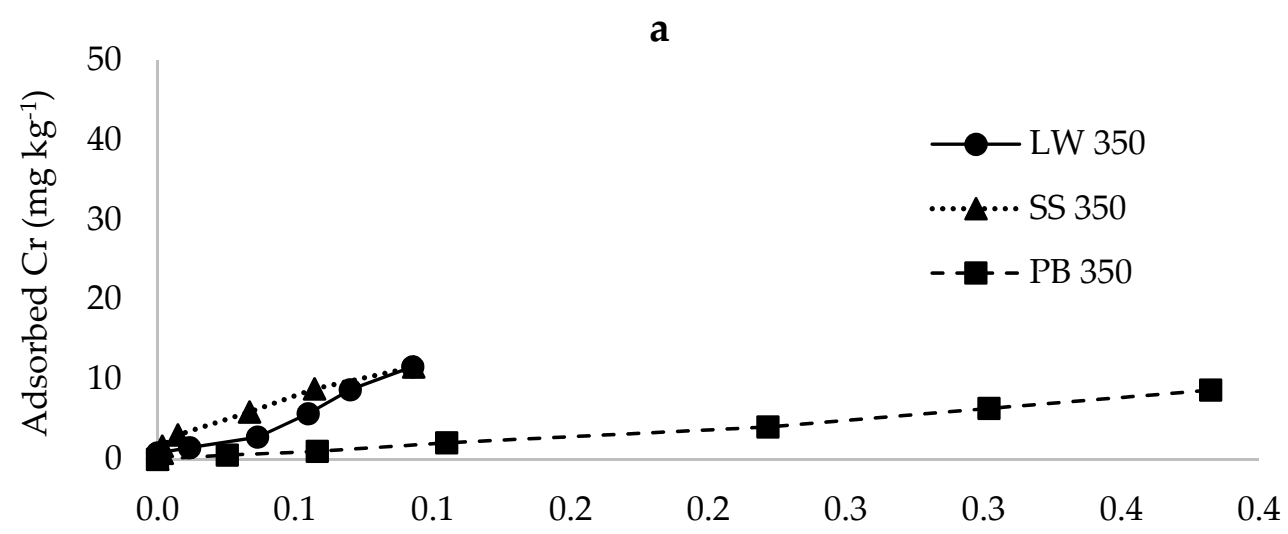

Equilibrium Cr Concentration (mg L-1)
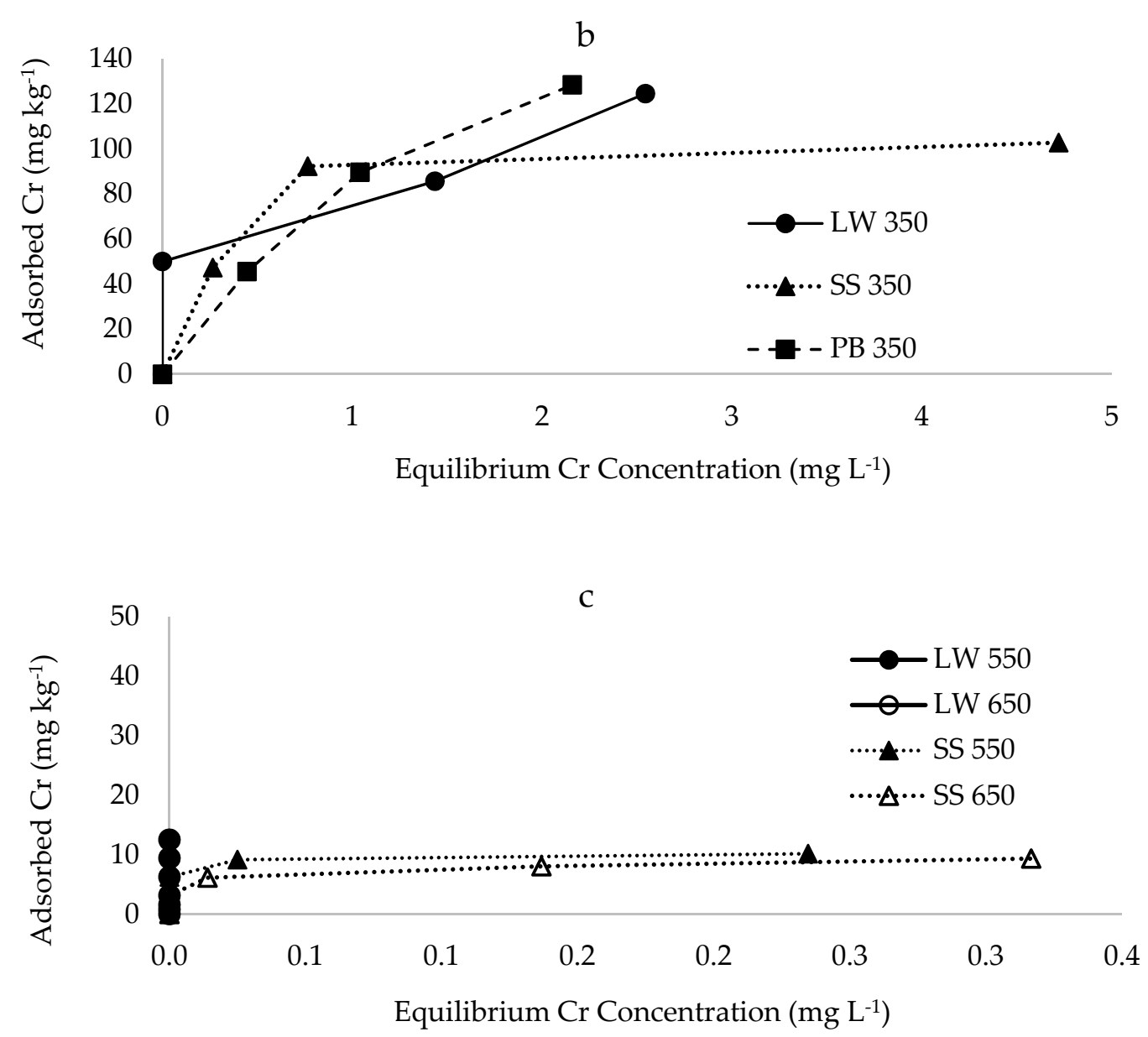

Figure 5. Sorption isotherms of chromium from: (a) effluent on biochar pyrolysed at $350{ }^{\circ} \mathrm{C}$, (b) single metal on biochar pyrolysed at $350^{\circ} \mathrm{C}$ and (c) effluent on biochar pyrolysed at 550 and $650{ }^{\circ} \mathrm{C}$. $\mathrm{LW}=$ latrine waste biochar, $\mathrm{SS}=$ sewage sludge biochar, $\mathrm{PB}=$ pine-bark biochar. 


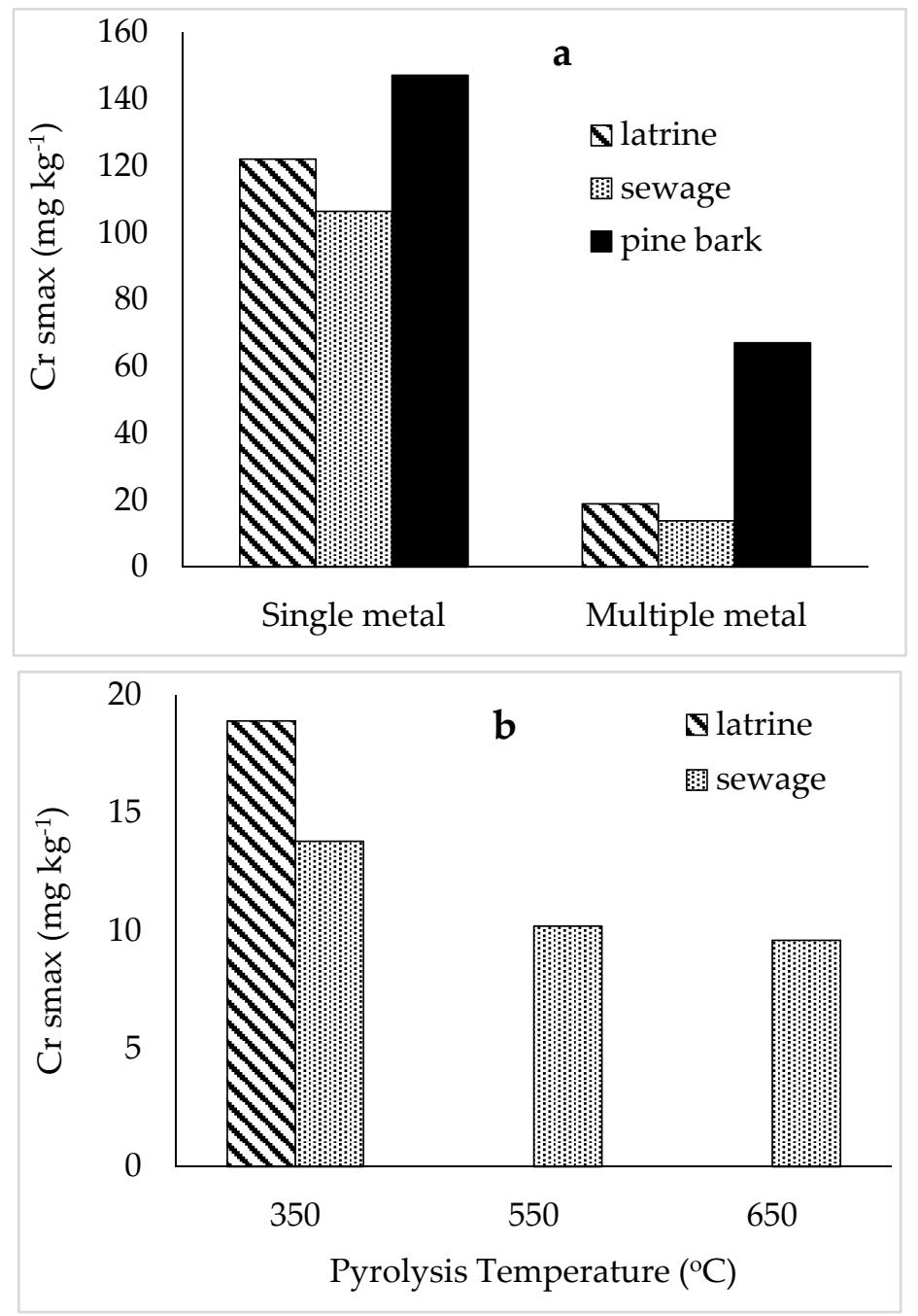

Figure 6. Maximum chromium sorption on faecal and pine-bark biochar pyrolysed at $350{ }^{\circ} \mathrm{C}(\mathbf{a})$ and on faecal biochar at increasing pyrolysis temperatures $(\mathbf{b})$.

Table 3. The $b\left(\mathrm{~L} \mathrm{~kg}^{-1}\right)$ and $r^{2}$ values of linearized Langmuir models of chromium on biochar from latrine waste, sewage sludge and pine bark.

\begin{tabular}{ccccc}
\hline \multirow{2}{*}{ Biochar Feedstock } & \multicolumn{4}{c}{$\boldsymbol{b}$-Value and $\left(\boldsymbol{r}^{\mathbf{2}}\right)$} \\
\cline { 2 - 5 } & \multicolumn{2}{c}{ Source of Metals $\left(\mathbf{3 5 0}^{\circ} \mathbf{C}\right.$ Pyrolysis) } & \multicolumn{1}{c}{ Pyrolysis Temperature (Metals from Effluent) } \\
\cline { 2 - 5 } & Aqueous Solution & Effluent & $\mathbf{5 5 0}{ }^{\circ} \mathbf{C}$ & $\mathbf{6 5 0}^{\circ} \mathbf{C}$ \\
\hline Latrine waste & $5.47(0.92)$ & $9.64(0.19)$ & - & - \\
Sewage sludge & $6.71(1.00)$ & $38.3(0.92)$ & $980(1.00)$ & $64.8(1.00)$ \\
Pine-bark & $2.06(0.83)$ & $0.29(0.31)$ & - & - \\
\hline
\end{tabular}

${ }^{*} \mathrm{No} \mathrm{Cr}$ sorption occurred on latrine waste biochar at 550 and $650{ }^{\circ} \mathrm{C}$.

\subsection{SEM-EDS Chemical Composition of Biochars with Sorbed Metals}

Major elements from the EDS spectra are tabulated in Table 4 with $\mathrm{C}$ and $\mathrm{O}$ being dominant for all biochar types. Molar O:C ratios of the biochars were highest on latrine waste and least on pine-bark biochar. Where sorption was done with effluent (50\% dilution), the concentrations of $\mathrm{Zn}, \mathrm{Cu}$ and $\mathrm{Cr}$ were higher than in the control for latrine waste and sewage sludge biochar, with only $\mathrm{Cr}$ detected on pine-bark biochar. 
Table 4. Concentrations of carbon, oxygen, copper, chromium and zinc (\%) on biochar types pyrolysed at $350^{\circ} \mathrm{C}$ after sorption study with or without effluent.

\begin{tabular}{ccccc}
\hline \multirow{2}{*}{ Solution Used for Sorption } & \multirow{2}{*}{ Element (weight \%) } & \multicolumn{3}{c}{ Biochars } \\
\cline { 3 - 5 } & & Pine-Bark & Sewage Sludge & Latrine Waste \\
\hline \multirow{3}{*}{ No effluent } & $\mathrm{C}$ & 71.9 & 60.9 & 34.0 \\
& $\mathrm{O}$ & 28.1 & 29.0 & 42.7 \\
& $\mathrm{O}: \mathrm{C}$ & 0.29 & 0.36 & 0.94 \\
& $\mathrm{Cu}$ & $*$ & 0.01 & $*$ \\
$\mathrm{Cr}$ & $*$ & 0.06 & $*$ \\
\hline \multirow{2}{*}{$50 \%$ effluent } & $\mathrm{Zn}$ & $*$ & 0.05 & 43.9 \\
& $\mathrm{C}$ & 74.6 & 61.7 & 0.70 \\
& $\mathrm{O}$ & 25.4 & 28.8 & 0.09 \\
& $\mathrm{O}: \mathrm{C}$ & 0.26 & 0.35 & 0.18 \\
& $\mathrm{Cu}$ & 0.03 & 0.07 & 0.09 \\
\hline
\end{tabular}

* indicate non-detection of the metals.

\subsection{Regression Analysis on Parameters Affecting Sorption of Metals from Effluents}

Best-fit models of stepwise regression analysis results for $\mathrm{Zn}, \mathrm{Cu}$ and $\mathrm{Cr}$ sorption and physicochemical properties of different biochars are presented in Table 5. Volatile matter, ash and fixed $\mathrm{C}$ contents and $\mathrm{pH}$ are the most influential biochar parameters on $\mathrm{Zn}$ sorption on biochars used in this study. These predictor parameters were significantly influential (at 95\% level) for the best-fit model which explained $99 \%$ of the variation. The model indicates that sorption maximum of $\mathrm{Zn}$ is likely to increase with increase in volatile, ash, fixed $\mathrm{C}$ and $\mathrm{pH}$. The best-fit model from step-wise regression revealed that the combined effects of ash and fixed $\mathrm{C}$ content of the biochar significantly influenced $\mathrm{Cu}$ sorption on the biochars. The model, which explained $94 \%$ of variation of $\mathrm{Cu}$ sorption on these biochars, reveals that copper sorption on these biochars is decreased if ash and fixed $\mathrm{C}$ increase. The computed stepwise regression analysis for $\mathrm{Cr}$ sorption showed the highly significant influence of ash content and BET surface area. An increase in these two predictor variables decrease $\mathrm{Cr}$ sorption, with the two variables explaining $96 \%$ of variation $\mathrm{Cr}$ sorption on these biochar types.

Table 5. Step-wise regression analysis for parameters affecting $\mathrm{Zn}, \mathrm{Cu}$ and $\mathrm{Cr}$ sorption maximum: presentation of the best-fit models.

\begin{tabular}{|c|c|c|c|}
\hline Predictor Variable & Parameter Estimates & Standard Error & $r^{2}$ \\
\hline \multicolumn{4}{|c|}{ Zinc } \\
\hline Intercept & -37760.85 & 7293.96 & \\
\hline Volatile (\%) & $439.08 *$ & 84.09 & \\
\hline Ash (\%) & 299.51 * & 64.13 & \\
\hline Fixed C (\%) & $259.64 *$ & 57.91 & \\
\hline $\mathrm{pH}$ & 1094.26 * & 122.69 & 0.9889 \\
\hline \multicolumn{4}{|c|}{ Copper } \\
\hline Intercept & 535.73 & 62.59 & \\
\hline Ash (\%) & $-4.49^{* *}$ & 0.65 & \\
\hline Fixed C (\%) & $-8.36^{* *}$ & 1.08 & 0.9381 \\
\hline \multicolumn{4}{|c|}{ Chromium } \\
\hline Intercept & 21.32 & 1.83 & \\
\hline Ash (\%) & $-0.17^{* *}$ & 0.02 & \\
\hline $\operatorname{BET}\left(\mathrm{m}^{2} \mathrm{~g}^{-1}\right)$ & $-0.25^{* * *}$ & 0.03 & 0.9604 \\
\hline
\end{tabular}

$*, * * * * *$ Indicates the significance at the $95 \%, 99 \%$ and $99.9 \%$ level, respectively. 


\section{Discussion}

The higher $\mathrm{Zn}$ and $\mathrm{Cu}$ sorption maxima of biochar from latrine waste and sewage sludge than pine-bark biochar, both for multiple metal effluent and single metal solution, could be related to biochar characteristics as affected by feedstock. Faecal biochar had higher ash, P content and $\mathrm{pH}$ than pine-bark biochar, which could have supported precipitation. Zhou et al. [30] reported that peanut-shell biochar with ash had higher $\mathrm{Cu}$ sorption than where the ash was removed. The relationship of $\mathrm{Zn}$ sorption with ash content of biochar was also in agreement with [31], who reported that higher ash released hydroxide and carbonates, which formed precipitates with Zn. Hegazi [32] also reported that effective removal of metals, including, $\mathrm{Cu}$ was increased by higher ash content, with precipitation of the metals on biochar occurring due to phosphates, carbonates and hydroxides [24,30]. This view was supported by the results of the stepwise regression analysis, which showed positive effects of $\mathrm{pH}$ and ash, in addition to volatile matter and fixed $\mathrm{C}$. The higher ash and $\mathrm{pH}$, together with higher $\mathrm{P}$, in the latrine waste and sewage sludge biochar types used in this study, could, therefore, have facilitated precipitation of $\mathrm{Zn}$ and $\mathrm{Cu}$. However, stepwise regression analysis showed that $\mathrm{Cu}$ sorption was reduced by higher ash and fixed C contents, while $C r$ was reduced by ash and specific surface area, suggesting contributions of different mechanisms between all three metals. Although sewage sludge biochar had lower ash than that from latrine waste, the higher P could have contributed in greater precipitation. The trend of $\mathrm{Cu}$ sorption on the biochar types was in agreement with [19], who reported that dairy manure biochar was more efficient in removing $\mathrm{Cu}$ than that from plant (rice husk) material. The sorbed $\mathrm{Cu}$ and $\mathrm{Zn}$ were supported by results of SEM-EDS, where the elements were higher than in the control. The ash content of pine-bark biochar was too low to cause significant precipitation of $\mathrm{Zn}$ and $\mathrm{Cu}$ sorption. Based on these results, biochar from sewage sludge would be more effective as a sorbent to remove $\mathrm{Zn}$ and/or $\mathrm{Cu}$ from multi-metal effluents where any of these metals are dominant, while latrine waste biochar would be more effective for single metal solutions.

The higher $\mathrm{Cr}$ sorption capacity of biochar from pine-bark than from sewage sludge, in single metal solutions, suggests that a different mechanism from those of $\mathrm{Zn}$ and $\mathrm{Cu}$, on this biochar. This trend was similar to that of surface area and cation exchange capacity (CEC). The higher surface area and CEC could have enhanced retention of $\mathrm{Cr}$ cations of the pine-bark biochar through ion exchange mechanism. Ding et al. [33] reported that hydroxyl and methyl functional groups were essential for the sorption and reduction of $\mathrm{Cr}$ (VI) to $\mathrm{Cr}(\mathrm{III})$, which precipitates with phosphate. Complexation, an important mechanism for Cr sorption [34], depends on the abundance of these functional groups, which in this research, declined with pyrolysis temperature on pine-bark biochar. The isotherms suggests that all the $\mathrm{Cr}$ was retained on latrine waste biochar at higher pyrolysis temperatures and this suggest that these important chemical functional groups (hydroxyl and methyl) were effective [35,36], as indicated by the decline in atomic ratio of $\mathrm{H} / \mathrm{C}$. The results of $\mathrm{Cr}$ sorption suggested that, in effluents where $\mathrm{Cr}$ is the dominant pollutant, pine-bark biochar would be more appropriate as a sorbent than biochar from latrine waste and sewage sludge.

The higher $\mathrm{Zn}$ sorption on all biochar types produced at $350{ }^{\circ} \mathrm{C}$ in multi-metal than single metal system was contrary to some findings in the literature [26]. Although [26] reported higher sorption of $\mathrm{Cu}$ than $\mathrm{Zn}$ in binary solution with equal concentrations of the two metals, competition with $\mathrm{Zn}$ at 20 times higher concentration, could have suppressed $\mathrm{Cu}$ sorption. Metal concentration play a significant role in the rate of adsorption [37]. The higher $\mathrm{Zn}$ and lower $\mathrm{Cu}$ and $\mathrm{Cr}$ sorption, in the multi-metal than single metal solutions, indicated that competitive sorption of the metals was affected by relative concentrations in the effluent, which favoured $\mathrm{Zn}$ sorption. The extremely higher $\mathrm{Zn}$ in the effluent than $\mathrm{Cu}$ and $\mathrm{Cr}$ could have precipitated with the hydroxides, carbonates and phosphates from the ash at the expense of $\mathrm{Cu}$ and $\mathrm{Cr}$, which remained in solution. Competitive sorption of metals by different biochars has been reported previously [26]. The acidic nature of the effluent could also have lowered the CEC of the materials, which together with lower concentrations (relative to $\mathrm{Zn}$ ) lowered $\mathrm{Cu}$ and $\mathrm{Cr}$ sorption, when compared to single metal solutions. Park et al. [38] indicated that single-metal system of $\mathrm{Zn}$ resulted in $38.6 \mathrm{mg} \mathrm{g}^{-1}$ sorption while binary-metal system, with equal concentrations with $\mathrm{Cu}$, 
yielded $7.9 \mathrm{mg} \mathrm{Zn}^{-1}$ on rice straw biochar. Zhou et al. [36] also reported that Zn sorption on sewage sludge biochar was 5.91 and $2.48 \mathrm{mg} \mathrm{g}^{-1}$ in mono-metal and multi-metal solution, respectively.

In the current study, the lower $\mathrm{Cu}$ sorption values in single metal solution than in multiple metal effluent, except for pine-bark, could be attributable to high $\mathrm{Zn}$ concentration and competition, which was higher than the other elements. Mishra et al. [37] reported that adsorbent dosage and metal concentration play a significant role in the rate and quantity of adsorption [37]. Park et al. [38] also reported lower values of $\mathrm{Cu}$ sorption in multi-metal $\left(40.2 \mathrm{mg} \mathrm{g}^{-1}\right)$ than single metal solutions (56.5 $\left.\mathrm{mg} \mathrm{g}^{-1}\right)$ due to competitive sorption with co-existing metals [34] especially $\mathrm{Zn}$. The lower sorption of $\mathrm{Cr}$ from multi-metal than single metal model could be explained by competition for sorption sites, with $\mathrm{Zn}$ and $\mathrm{Cu}$, which had 170 and eight times higher concentration, respectively. In studies comparing single and competitive metal sorption, $\mathrm{Cr}$ was found to be easily exchanged and substituted by other metals such as $\mathrm{Cu}$ and $\mathrm{Zn}[26,39]$. Since $\mathrm{Cr}$ sorption also follows the trend of surface area and CEC than the other two metals, the acidic effluent could have lowered the CEC of the biochars, lowering the retention of $\mathrm{Cr}$ when compared with single metal solutions.

The lack of change of $\mathrm{Zn}$ sorption and lower $\mathrm{Cu}$ sorption maximum on sewage sludge with increasing pyrolysis temperature could be explained by the increase in $\mathrm{P}$ in the sewage sludge biochar. The extremely high concentration of $\mathrm{Zn}$ could have precipitated with the increased $\mathrm{P}$ in the sewage sludge biochar, suppressing $\mathrm{Cu}$ sorption on the same biochar. The decrease in $\mathrm{Cu}$ sorption on sewage sludge biochar, with increasing pyrolysis temperature could be due to loss of oxygen-containing functional group such $\mathrm{C}=\mathrm{O}$ stretching of aldehyde and carbonate ions at 550 and $650^{\circ} \mathrm{C}$ [28]. The reason for the decline of $\mathrm{Zn}$ sorption and no change in $\mathrm{Cu}$ sorption on latrine waste with increasing pyrolysis temperature was not clear. However, the $\mathrm{pH}$ of the equilibrium solution could have contributed. Other studies reported that adsorption capacity for $\mathrm{Cu}$ (II) by biochar was increased with increase in $\mathrm{pH}$ from 2.0 to 6.0 especially on Fe and Zn laden biochar [36]. However, [31] reported that biochar produced from rice straw at low pyrolysis temperature $\left(300\right.$ and $\left.400{ }^{\circ} \mathrm{C}\right)$ showed the higher removal capacity of metals than those at higher pyrolysis temperatures. Zinc sorption may decrease with increase in pyrolysis temperature owing to loss of chemical functional groups that offer site for physical adsorption. Increasing pyrolysis temperature would have formed less reactive biochar rich in condensed C.

Several other studies reported that pyrolysis temperature influences sorption capacities of different biochars $[17,24,31]$. For example, $\mathrm{Cr}$ (III) removal by low pyrolysis temperature biochar (100 and $\left.300{ }^{\circ} \mathrm{C}\right)$ was higher than high pyrolysis temperature $\left(500\right.$ and $\left.700{ }^{\circ} \mathrm{C}\right)$ [31]. On the other hand, removal of $\mathrm{Cu}, \mathrm{Zn}$ and $\mathrm{Cd}$ by $350^{\circ} \mathrm{C}$ dairy manure biochar was more efficient than $200^{\circ} \mathrm{C}$ biochar of the same feedstock [24]. The current study suggested that, at lower pyrolysis temperature, sewage sludge and latrine waste biochar types were more effective than pine-bark biochar, while at higher temperature, sewage sludge was better that latrine waste biochar for sorption of $\mathrm{Zn}$.

Bonding energy is a key quantity describing the strength of the interaction of molecules with the surface [40]. The bonding energy for $\mathrm{Zn}$ was lower on pine-bark than on faecal waste derived biochars. The strength of the binding between a given metal and a surface may vary from reaction site to the other [41]. It may be because each energy represent the contribution made by the bond to the total atomization energy of the concerned molecule [42]. Hence, at the greater adsorption density (ions $/ \mathrm{m}^{2}$ specific surface area), the strongest binding site becomes limiting and average binding constant decreases even though the total number of available unoccupied binding site is large [41]. The lower bonding energy constant of $\mathrm{Cu}$ for effluent than single metal solution suggested that sorbed $\mathrm{Cu}$ could easily be desorbed. On the other hand, the higher coefficient of bonding energy of $\mathrm{Cr}$ on for pine-bark biochar than latrine waste and sewage sludge biochar, suggests stronger bonding, possibly minimising the possibility of desorption. This further supported the view that a different sorption mechanism could have been involved. The lower bonding energy constants of $\mathrm{Cr}$ for single metal solutions than effluent for all biochar types at $350{ }^{\circ} \mathrm{C}$, suggested weaker bonding, associated with easier desorption. 


\section{Materials and Methods}

\subsection{Biochar}

The biochar types used in this study were produced from two faecal wastes (sewage sludge and latrine waste) and pine-bark. The preparation of the biochars from the different feedstocks was as detailed in [29]. Briefly, it involved drying at $70^{\circ} \mathrm{C}$ for $24 \mathrm{~h}$ and milling $(<5 \mathrm{~mm})$ before slow pyrolysis for $2 \mathrm{~h}$ in a muffle furnace, under limited oxygen at 350, 550 and $650{ }^{\circ} \mathrm{C}[43,44]$. The biochar was weighed before characterization [45] and selected characteristics of the biochars are shown in Tables 6 and 7.

Table 6. Selected physicochemical properties of biochars used in this study.

\begin{tabular}{|c|c|c|c|c|c|c|c|}
\hline Biochar & $\mathrm{pH}(\mathrm{KC})$ & Ash (\%) & $\begin{array}{c}\text { Fixed C } \\
(\%)\end{array}$ & $\begin{array}{c}\text { Volatile } \\
(\%)\end{array}$ & $\begin{array}{c}\text { SSA } \\
\left(\mathrm{mg}^{-1}\right)\end{array}$ & $\begin{array}{c}P V \\
\left(\mathrm{~cm}^{3} \mathrm{~g}^{-1}\right)\end{array}$ & $\begin{array}{c}\text { Pore Size } \\
\text { (£) }\end{array}$ \\
\hline \multicolumn{8}{|c|}{ Latrine Waste } \\
\hline 350 & 6.9 & 84.3 & 5.5 & 10.27 & 7.54 & 0.035 & 183 \\
\hline 550 & 7.1 & 89.9 & 4.4 & 5.70 & 23.7 & 0.053 & 91.0 \\
\hline 650 & 7.3 & 92.7 & 4.2 & 3.10 & 25.7 & 0.052 & 81.2 \\
\hline \multicolumn{8}{|c|}{ Sewage Sludge } \\
\hline 350 & 6.0 & 49.2 & 14.6 & 31.13 & 0.29 & 0.0008 & 113 \\
\hline 550 & 7.7 & 66.2 & 23.9 & 9.80 & 1.58 & 0.0051 & 130 \\
\hline 650 & 8.0 & 69.4 & 23.3 & 7.23 & 4.21 & 0.0073 & 50.6 \\
\hline \multicolumn{8}{|c|}{ Pine-Bark } \\
\hline 350 & 4.3 & - & 57.6 & 39.47 & 73.1 & 0.053 & 28.8 \\
\hline
\end{tabular}

* Biochars from pine-bark produced at 550 and $650{ }^{\circ} \mathrm{C}$ were not used in this study. SSA, PV and Pore size represent BET specific surface area, pore volume and average pore size, respectively.

Table 7. Total composition of selected elements and CEC in biochars used in this study.

\begin{tabular}{|c|c|c|c|c|c|c|c|}
\hline \multirow{2}{*}{ Biochar } & \multirow{2}{*}{ N (\%) } & \multirow{2}{*}{$P\left(g_{k g}^{-1}\right)$} & $\mathbf{K}$ & $\mathrm{Ca}$ & $\mathrm{Mg}$ & $\mathrm{Na}$ & \multirow{2}{*}{ CEC (cmolc kg $\left.{ }^{-1}\right)$} \\
\hline & & & \multicolumn{4}{|c|}{$\left(\mathrm{mg} \mathrm{kg}^{-1}\right)$} & \\
\hline \multicolumn{8}{|c|}{ Latrine Waste } \\
\hline 350 & 1.04 & 25.3 & 368 & 1953 & 374 & 207 & 5.09 \\
\hline 550 & 0.71 & 24.9 & 407 & 3469 & 493 & 322 & 4.91 \\
\hline 650 & 0.44 & 25.0 & 227 & 3769 & 525 & 225 & 5.65 \\
\hline \multicolumn{8}{|c|}{ Sewage Sludge } \\
\hline 350 & 5.45 & 22.6 & 1290 & 1097 & 593 & 462 & 4.17 \\
\hline 550 & 2.64 & 38.1 & 489 & 557 & 418 & 101 & 2.31 \\
\hline 650 & 2.77 & 37.9 & 567 & 640 & 565 & 235 & 2.40 \\
\hline \multicolumn{8}{|c|}{ Pine-Bark } \\
\hline 350 & 0.69 & 2.6 & 1780 & 1200 & 280 & 410 & 15.0 \\
\hline
\end{tabular}

\subsection{Industrial Effluent}

Untreated industrial effluent was obtained from ES \& LC Manufacturing (Pietermaritzburg, South Africa), an electroplating company in Pietermaritzburg $\left(29^{\circ} 39^{\prime} 03.03^{\prime \prime} \mathrm{S}\right.$ and $\left.30^{\circ} 24^{\prime} 43.53^{\prime \prime} \mathrm{E}\right)$. The company specializes in making and electroplating satellite mounting brackets. The effluent was analysed for $\mathrm{pH}$, electric conductivity (EC), and chemical oxygen demand (COD), according to standard methods [46]. Total elemental composition of the effluent was analysed using the inductively coupled plasma-optical emission spectrometry (ICP-OES, Varian 720-ES series, by Varian Australia 
Pty Ltd) [47]. This effluent had low $\mathrm{pH}$, high electrical conductivity and a variety of heavy metals, as indicated in Table 8. Three metals had concentrations higher than the critical limits for disposal into the environment and were in the order $\mathrm{Zn}>\mathrm{Cu}>\mathrm{Cr}$.

Table 8. Electrical conductivity, $\mathrm{pH}$ and concentrations of heavy metals in the effluent used.

\begin{tabular}{ccc}
\hline Parameters & Critical Limit (DWAF, 2004 In [48]) & Effluent \\
\hline $\mathrm{pH}$ & $5.5-9.5$ & $2.5 \pm 0.0$ \\
$\mathrm{EC}\left(\mathrm{mS} \mathrm{m}^{-1}\right)$ & $70-150$ & $1383 \pm 4.2$ \\
$\mathrm{COD}\left(\mathrm{mg} \mathrm{O}_{2} \mathrm{~L}^{-1}\right)$ & $<75$ & $510 \pm 36.8$ \\
$\mathrm{Cr}\left(\mathrm{\mu g} \mathrm{L}^{-1}\right)$ & $<0.05$ & $1.25 \pm 0.02$ \\
$\mathrm{Cu}\left(\mathrm{mg} \mathrm{L}^{-1}\right)$ & $<0.01$ & $10.2 \pm 0.24$ \\
$\mathrm{Zn}\left(\mathrm{mg} \mathrm{L}^{-1}\right)$ & $<0.10$ & $212 \pm 13.8$ \\
\hline
\end{tabular}

Critical limits (DWAF, 2004). Metal ratios: $\mathrm{Zn}: \mathrm{Cu}=21: 1, \mathrm{Zn}: \mathrm{Cr}=170: 1, \mathrm{Cu}: \mathrm{Cr}=8: 1$.

\subsection{Sorption of Elements from Single Metal Solutions and Effluent with Multiple Metals by Biochars}

The batch sorption study with biochar from latrine waste, sewage sludge and pine-bark biochar, pyrolysed at $350{ }^{\circ} \mathrm{C}$, was done with Zn solutions of increasing concentrations. An analytical grade stock solution of $1000 \mathrm{mg} \mathrm{Zn} \mathrm{L}{ }^{-1}$ was diluted in a $0.01 \mathrm{M} \mathrm{CaCl}_{2}$ as a background electrolyte. The solution was diluted to 5, 10,15, 20, and $25 \mathrm{mg} \mathrm{Zn} \mathrm{L}{ }^{-1}$ solutions with $0.01 \mathrm{M} \mathrm{CaCl}_{2}$. The $0.01 \mathrm{M} \mathrm{CaCl}_{2}$ solution was used as the $0 \mathrm{mg} \mathrm{L}^{-1}$ concentration. The batch tests were replicated three times and blanks were run concurrently [8]. The $\mathrm{Zn}$ solutions $(25 \mathrm{~mL})$ were added to centrifuge tubes containing $2.5 \mathrm{~g}$ biochar samples. The suspensions were shaken at $180 \mathrm{r} \mathrm{min}^{-1}$ at constant temperature $\left(25^{\circ} \mathrm{C}\right)$ for $24 \mathrm{~h}$ [49] on a reciprocating shaker. The suspensions were centrifuged at $9440 \times g$ for 10 min and the supernatants filtered through Whatman No. 42 filter paper [49]. A Fast Sequential Atomic Absorption Spectrometer (Model AA280FS) was used to measure Zn concentration in the supernatant. Amount of $\mathrm{Zn}$ sorbed $(S)$ was calculated as the difference between amount added and amount in the equilibrium solution, using Equation (1) [50]:

$$
S=\frac{\left(C_{0}-C_{\mathrm{e}}\right) \times V}{W}
$$

where $S$ is the amount of $\mathrm{Zn}$ sorbed $\left(\mathrm{mg} \mathrm{kg}^{-1}\right), C_{0}$ and $C_{\mathrm{e}}$ are the initial and equilibrium solution $\mathrm{Zn}$ concentrations $\left(\mathrm{mg} \mathrm{L}^{-1}\right), V$ is the solution volume $(\mathrm{L})$, and $W$ is the adsorbent weight $(\mathrm{kg})$.

The same batch sorption study was repeated with solutions of $\mathrm{Cu}$ and $\mathrm{Cr}$, at the same concentrations as $\mathrm{Zn}$. Only the $\mathrm{pH}$ of metal solutions with increasing concentrations were measured and reported as shown in Table 9.

Table 9. $\mathrm{pH}$ of single metal solutions used in the study.

\begin{tabular}{cccc}
\hline Metal Concentration & $\mathbf{C u}$ & $\mathbf{C r}$ & Zn \\
\hline 0 ppm & 6.11 & 6.09 & 6.09 \\
$5 \mathrm{ppm}$ & 2.83 & 5.54 & 2.84 \\
$10 \mathrm{ppm}$ & 2.54 & 5.50 & 2.56 \\
$15 \mathrm{ppm}$ & 2.31 & 5.43 & 2.40 \\
$20 \mathrm{ppm}$ & 2.22 & 5.39 & 2.25 \\
$25 \mathrm{ppm}$ & 1.96 & 5.27 & 2.17 \\
\hline
\end{tabular}

Another batch sorption study with the same biochars was conducted with dilutions of the industrial effluent. The effluent was diluted to the selected metal concentrations with $0.01 \mathrm{M} \mathrm{CaCl}_{2}$ solution (background electrolyte). Biochar ( $2.5 \mathrm{~g}$ ) was mixed with $25 \mathrm{~mL}$ of $0 \%, 6.25 \%, 12.5 \%$ and $25 \%$ for $\mathrm{Zn}$ and $0 \%, 12.5 \%, 25 \%, 50 \%, 75 \%$ and $100 \%$ of the effluent for $\mathrm{Cu}$ and $\mathrm{Cr}$. These dilutions corresponded to $0,13.3,26.5$ and $53.0 \mathrm{mg} \mathrm{L}^{-1}$ for $\mathrm{Zn} ; 0,0.638,1.28,2.55,5.10,7.65$ and $10.2 \mathrm{mg} \mathrm{L}^{-1}$ for $\mathrm{Cu}$; and $0,0.078,0.156,0.313,0.625,0.938$ and $1.25 \mathrm{mg} \mathrm{Cr} \mathrm{L}^{-1}$. The batch sorption study with the effluent was repeated with biochar produced from latrine waste and sewage sludge pyrolysed at 
550 and $650^{\circ} \mathrm{C}$ to determine effects of pyrolysis temperature. Pine-bark biochars were not used because they showed low $\mathrm{Cd}$ sorption in the preliminary study, and when pyrolysed at $350{ }^{\circ} \mathrm{C}, \mathrm{Zn}$ and $\mathrm{Cu}$ sorbed was low. To estimate the sorption capacity and parameter related to energy of bonding of heavy metals onto biochar, the experimental data were fitted to the Langmuir sorption model (Equation (2)), from which the $S_{\max }$ and $b$-values were calculated [24,51].

$$
\frac{C}{S}=\frac{1}{S_{\max } \times b}+\frac{C}{S_{\max }}
$$

where $C$ is equilibrium concentration; $S$, amount of metal sorbed; $S_{\max }$ was maximum amount of metal that the biochar can sorb; and $b$ is constant related to binding affinity.

The solid retained on the filter paper was collected for Scanning Electron Microscopy-Energy Dispersive X-ray Spectroscopy (SEM-EDS) to determine abundance of specific available and adsorbed elements [24].

\subsection{Surface Characteristics of Resultant Biochars}

The ZEISS EVO LS15 scanning electron microscopy-energy dispersive X-ray spectroscopy (SEM, Oberkochen, Germany) was used to analyse the external morphology (surface characteristics) and qualitative chemical composition of the biochars. The analyses involved a beam of electrons generated in a vacuum, which is collimated by electromagnetic condenser lenses and scanned across the sample surface by a coil. Secondary electrons were then made to fall on the surface of a photosensitive plate in a photomultiplier tube. Amplified electrons are send to phosphorescent screen which provided magnified image of sample surface. Energy Dispersive X-ray Spectroscopy (EDS) was used to analyse the energy spectrum in order to determine abundance of specific available elements in a given sample. Figure 7 shows distinctive morphological structure of the $350{ }^{\circ} \mathrm{C}$ biochars. External morphology of the resultant biochars shows porous structure with some fissures and or flakes, which varied between biochars from the different feedstocks.

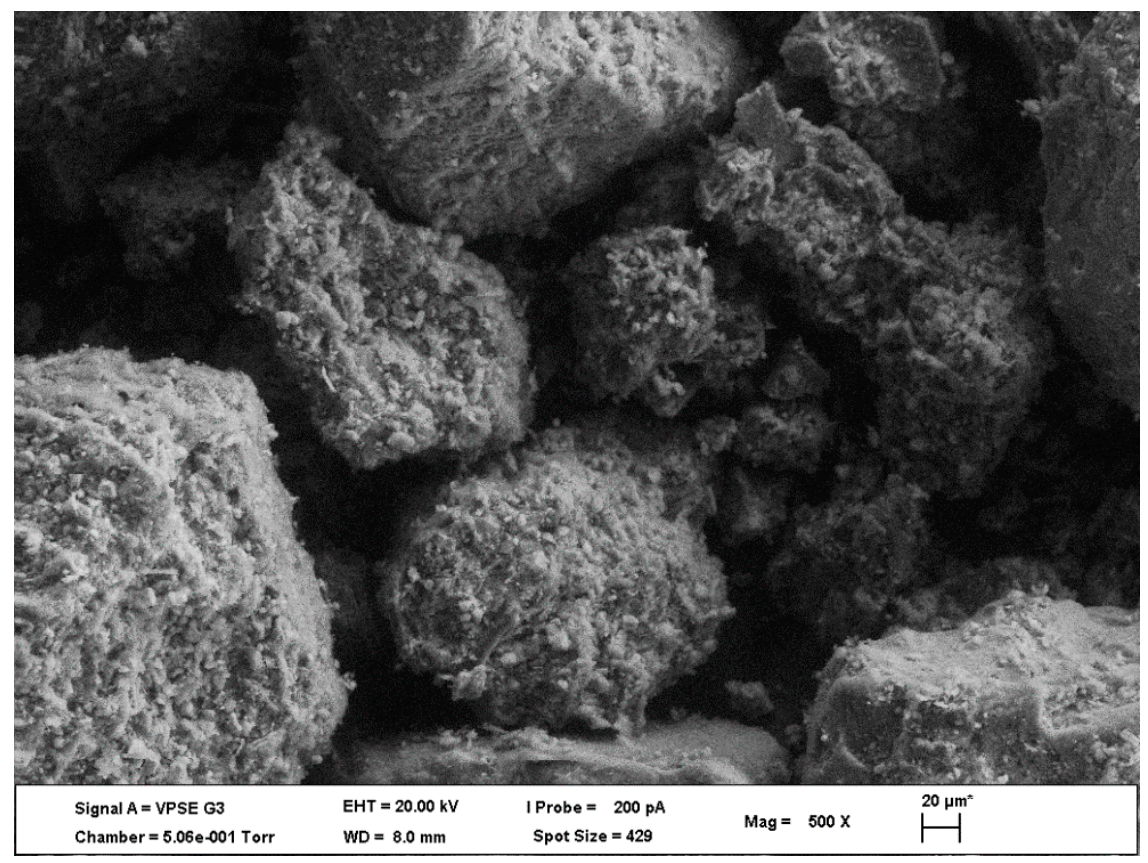

(a)

Figure 7. Cont. 


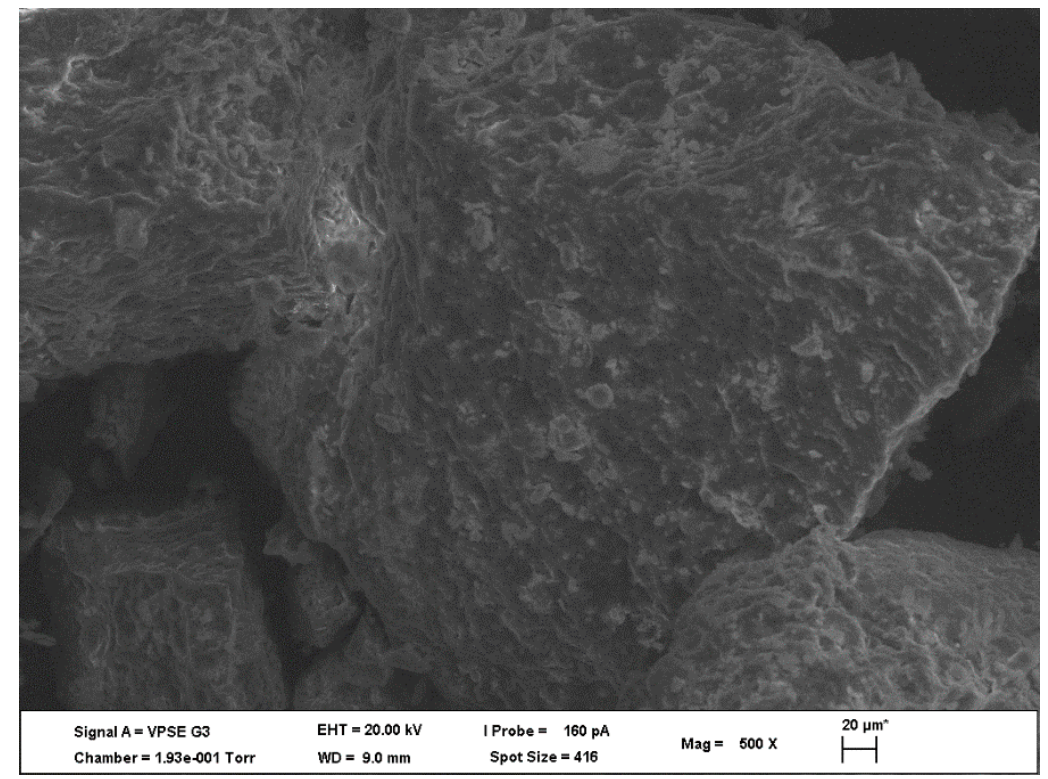

(b)

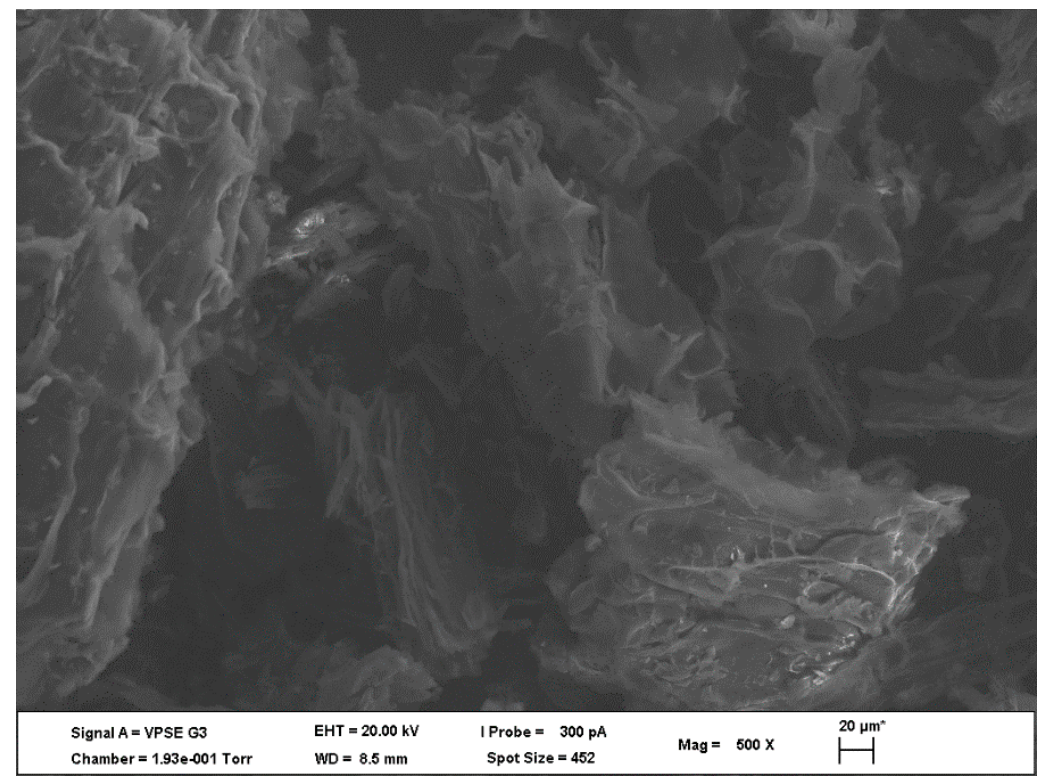

(c)

Figure 7. Morphological comparison of biochar types produced at $350{ }^{\circ} \mathrm{C}$ from (a) latrine waste, (b) sewage sludge and (c) pine bark.

\subsection{Statistical Analysis}

Stepwise regression derived from multiple regression analysis was used to determine the combined effect of biochar parameters on metal sorption capacity from the industrial effluent. The analysis identified the best-fit model by removing certain variables based on the $t$-statistics for estimated coefficients [52].

\section{Conclusions}

Biochar types from sewage sludge and latrine waste removed more $\mathrm{Zn}$ and $\mathrm{Cu}$ and less so for $\mathrm{Cr}$, from multiple metal effluent and single metal solutions, than pine-bark biochar. Sorption on the biochars was higher for $\mathrm{Zn}$ and lower for $\mathrm{Cu}$ and $\mathrm{Cr}$, from multi-metal effluent than from single metal 
solutions. Increase in pyrolysis temperature reduced sorption of $\mathrm{Zn}, \mathrm{Cu}$ and $\mathrm{Cr}$ from multi-metal effluent on latrine waste and sewage sludge biochar. Pine-bark biochar $\left(350^{\circ} \mathrm{C}\right)$ had higher $\mathrm{Cr}$ sorption than its counterpart latrine waste and sewage sludge both for multi-metal and single metal solution. Biochar derived from human faecal waste, pyrolysed at $350{ }^{\circ} \mathrm{C}$ promises to be an effective sorbent for removal of $\mathrm{Zn}, \mathrm{Cu}$ and $\mathrm{Cr}$ from solution, with greater sorption of $\mathrm{Zn}$ from multi-metal effluent on sewage sludge biochar, and from single metal solution on latrine waste biochar. The use of these feedstocks for biochar production from the stock-piles could alleviate their disposal challenges. The cost-effectiveness of the biochars will depend on the costs of drying the feedstocks and pyrolysis and the disposal strategies for the metal enriched biochars, which still need to be studied.

Author Contributions: Conceptualization, K.A.K. and P.M.; Methodology, K.A.K. and P.M.; Formal Analysis, K.A.K.; Investigation, K.A.K.; Resources, P.M.; Data Curation, K.A.K.; Writing-Original Draft Preparation, K.A.K.; Writing-Review and Editing, K.A.K. and P.M.; Visualisation, P.M.; Supervision, P.M.; Project Administration, P.M.; Funding Acquisition, K.A.K.

Funding: This research was funded by The WK Kellogg Foundation Southern Africa Scholarships.

Acknowledgments: The Pollution Research Group of the University of KwaZulu-Natal assisted with biochar production facilities.

Conflicts of Interest: The authors declare no conflict of interest. The funders had no role in the design of the study; in the collection, analyses, or interpretation of data; in the writing of the manuscript, and in the decision to publish the results.

\section{References}

1. Prasad, M.N.V. Cadmium toxicity and tolerance in vascular plants. Environ. Exp. Bot. 1995, 35, 525-545. [CrossRef]

2. Pellera, F.-M.; Gidarakos, E. Effect of dried olive pomace-Derived biochar on the mobility of cadmium and nickel in soil. J. Environ. Chem. Eng. 2015, 3, 1163-1176. [CrossRef]

3. Ghosh, M.; Singh, S.P. A comparative study of cadmium phytoextraction by accumulator and weed species. Environ. Pollut. 2005, 133, 365-371. [CrossRef]

4. Liang, C.; Xiao-Hua, L.; Zhen-Hua, Z.; Xiao-Tao, Z.; Rengel, Z.; Zhao-Pu, L. Cadmium Accumulation and Translocation in Two Jerusalem Artichoke (Helianthus tuberosus L.) Cultivars. Pedosphere 2011, 21, 573-580.

5. Kabata-Pendias, A. Trace Elements in Soils and Plants; CRC Press: London, UK, 2000.

6. Coumar, M.V.; Parihar, R.S.; Dwivedi, A.K.; Saha, J.K.; Rajendiran, S.; Dotaniya, M.L.; Kundu, S. Impact of pigeon pea biochar on cadmium mobility in soil and transfer rate to leafy vegetable spinach. Environ. Monit. Assess. 2016, 188, 31. [CrossRef] [PubMed]

7. Perez-Marin, A.B.; Zapata, V.M.; Ortuno, J.F.; Aguilar, M.; Saez, J.; Llorens, M. Removal of cadmium from aqueous solutions by adsorption onto orange waste. J. Hazard. Mater. B 2007, 139, 122-131. [CrossRef] [PubMed]

8. Mohan, D.; Pittman, C.U., Jr.; Bricka, M.; Smith, F.; Yancey, B.; Mohammad, J.; Steele, P.H.; Alexandre-Franco, M.F.; Gómez-Serrano, V.; Gong, H. Sorption of arsenic, cadmium, and lead by chars produced from fast pyrolysis of wood and bark during bio-oil production. J. Colloid Interface Sci. 2007, 310, 57-73. [CrossRef]

9. Cui, L.; Yan, J.; Li, L.; Quan, G.; Ding, C.; Chen, T.; Yin, C.; Gao, J.; Hussain, Q. Does biochar alter the speciation of $\mathrm{Cd}$ and $\mathrm{Pb}$ in aqueous solution? BioResources 2015, 10, 88-104. [CrossRef]

10. Ranade, V.V.; Bhandari, V.M. Industrial Wastewater Treatment, Recycling and Reuse; Elsevier Butterworth-Heinemann: Oxford, UK, 2014, ISBN 978-0-08-099968-5.

11. González-Viar, M.; Díez-Montero, R.; Molinos-Senante, M.; De-Florio, L.; Esteban-García, A.L.; Sala-Garrido, R.; Hernández-Sancho, F.; Tejero, I. Cost-effectiveness analysis of sewer mining versus centralized wastewater treatment: Case study of the Arga river basin, Spain. Urban Water J. 2016, 13, 321-330. [CrossRef]

12. Shi, G.; Cai, Q. Cadmium tolerance and accumulation in eight potential energy crops. Biotechnol. Adv. 2009, 27, 555-561. [CrossRef] 
13. Mohan, D.; Kumar, H.; Sarswat, A.; Alexandre-Franco, M.; Pittman, C.U., Jr. Cadmium and lead remediation using magnetic oak wood and oak bark fast pyrolysis bio-chars. Chem. Eng. J. 2014, 236, 513-528. [CrossRef]

14. Doble, M.; Kumar, A. Bio-Treatment of Industrial Effluents; Elsevier Butterworth-Heinemann: Oxford, UK, 2005, ISBN 0-7506-7838-0.

15. Namgay, T.; Singh, B.; Singh, B.P. Influence of biochar application to soil on the availability of $\mathrm{As}, \mathrm{Cd}, \mathrm{Cu}, \mathrm{Pb}$, and Zn to maize (Zea mays L.). Aust. J. Soil Res. 2010, 48, 638-647. [CrossRef]

16. Major, J. Biochar for Soil Remediation and Land Reclamation; International Biochar Initiative: Canandaigua, NY, USA, 2011.

17. Kim, W.-K.; Shim, T.; Kim, Y.-S.; Hyun, S.; Ryu, C.; Park, Y.-K.; Jung, J. Characterization of cadmium removal from aqueous solution by biochar produced from a giant Miscanthus at different pyrolytic temperatures. Bioresour. Technol. 2013, 138, 266-270. [CrossRef]

18. Li, J.; Li, Y.; Wu, Y.; Zheng, M. A comparison of biochars from lignin, cellulose and wood as the sorbent to an aromatic pollutant. J. Hazard. Mater. 2014, 280, 450-457. [CrossRef]

19. Trakal, L.; Bingol, D.; Pohorely, M.; Hruska, M.; Komarek, M. Geochemical and spectroscopic investigations of $\mathrm{Cd}$ and $\mathrm{Pb}$ sorption mechanisms on contrasting biochars: Engineering implications. Bioresour. Technol. 2014, 171, 442-451. [CrossRef]

20. Bogusz, A.; Oleszczuk, P.; Dobrowolski, R. Application of laboratory prepared and commercially available biochars to adsorption of cadmium, copper and zinc ions from water. Bioresour. Technol. 2015, 196, 540-549. [CrossRef]

21. Kuppusamy, S.; Thavamani, P.; Megharaj, M.; Venkateswarlu, K.; Naidu, R. Agronomic and remedial benefits and risks of applying biochar to soil: Current knowledge and future research directions. Environ. Int. 2016, 87, 1-12. [CrossRef]

22. McKay, G.; Porter, J.F. Equilibrium parameters for the sorption of copper, cadmium and zinc ions onto peat. J. Chem. Technol. Biotechnol. 1997, 69, 309-320. [CrossRef]

23. Chen, X.; Chen, G.; Chen, L.; Chen, Y.; Lehmann, J.; McBride, M.B.; Hay, A.G. Adsorption of copper and zinc by biochars produced from pyrolysis of hardwood and corn straw in aqueous solution. Bioresour. Technol. 2011. [CrossRef]

24. Xu, X.; Cao, X.; Zhao, L.; Wang, H.; Yu, H.; Gao, B. Removal of Cu, Zn, and Cd from aqueous solutions by the dairy manure-derived biochar. Environ. Sci. Pollut. Res. 2013, 20, 358-368. [CrossRef]

25. Kim, K.H.; Kim, J.-Y.; Cho, T.-S.; Choi, J.W. Influence of pyrolysis temperature on physicochemical properties of biochar obtained from the fast pyrolysis of pitch pine (Pinus rigida). Bioresour. Technol. 2012, 118, 158-162. [CrossRef]

26. Park, J.; Cho, J.; Ok, Y.S.; Kim, S.; Heo, J.; Delaune, R.D.; Kim, S. Comparison of single and competitive metal adsorption by pepper stem biochar. Arch. Agron. Soil Sci. 2016, 62, 617-632. [CrossRef]

27. Kolodynska, D.; Bak, J.; Kozio, M.; Pylychuk, L.V. Investigations of Heavy Metal Ion Sorption Using Nanocomposites of Iron-Modified Biochar. Nanoscale Res. Lett. 2017, 12, 433. [CrossRef]

28. Koetlisi, K.A.; Muchaonyerwa, P. Biochar Types from Latrine Waste and Sewage Sludge Differ in Physico-Chemical Properties and Cadmium Adsorption. Am. J. Appl. Sci. 2017, 14, 1039-1048. [CrossRef]

29. Koetlisi, A.K.; Muchaonyerwa, P. Pyrolysis temperature effects oy yield, physico-chemical characteristics of pine-bark biochars and cadmium sorption. Indian J. Environ. Prot. 2018, 38, 197-212.

30. Zhou, G.; Luo, J.; Liu, C.; Chu, L.; Ma, J.; Tang, Y.; Luo, S. A highly efficient polyampholyte hydrogel sorbent based fixed-bed process for heavy metal removal in actual industrial effluent. Water Res. 2016, 89, 151-160. [CrossRef]

31. Qian, L.; Zhang, W.; Yan, J.; Han, L.; Gao, W.; Liu, R.; Chen, M. Effective removal of heavy metal by biochar colloids under different pyrolysis temperatures. Bioresour. Technol. 2016, 206, 217-224. [CrossRef]

32. Hegazi, H.A. Removal of heavy metals from wastewater using agricultural and industrial wastes as adsorbents. HBRC J. 2013, 9, 276-282. [CrossRef]

33. Ding, W.; Peng, W.; Zeng, X.; Tian, X. Effects of phosphorus concentration on Cr (VI) sorption onto phosphorus-rich sludge biochar. Front. Environ. Sci. Eng. 2014, 8, 379-385. [CrossRef]

34. Li, H.; Dong, X.; Evandro, B.; Oliveira, L.M.D.; Chen, Y.; Ma, L.Q. Chemosphere mechanisms of metal sorption by biochars: Biochar characteristics and modifications. Chemosphere 2017, 178, 466-478. [CrossRef] 
35. Ahmed, N.; Rahman, M.; Won, S.; Shim, S. Biochar properties and eco-friendly applications for climate change mitigation, waste management, and wastewater treatment: A review. Renew. Sustain. Energy Rev. 2017, 79, 255-273. [CrossRef]

36. Zhou, D.; Liu, D.; Gao, F.; Li, M.; Luo, X. Effects of Biochar-Derived Sewage Sludge on Heavy Metal Adsorption and Immobilization in Soils. Int. J. Environ. Res. Public Health 2017, 14, 681. [CrossRef]

37. Mishra, S.R.; Chandra, R.; Kaila, A.J.; Darshi, B.S. Kinetics and isotherm studies for the adsorption of metal ions onto two soil types. Environ. Technol. Innov. 2017, 7, 87-101. [CrossRef]

38. Park, J.-H.; Wang, J.J.; Kim, S.-H.; Cho, J.-S.; Kang, S.-W.; Delaune, R.D.; Han, K.-J.; Seo, D.-C. Recycling of Rice Straw through Pyrolysis and Its Adsorption Behaviors for $\mathrm{Cu}$ and $\mathrm{Zn}$ Ions in Aqueous Solution. Colloids Surf. A Physicochem. Eng. Asp. 2017, 533, 330-337. [CrossRef]

39. Shah, B.A. Archive of SID Sorption isotherms and kinetics of chromium uptake from wastewater using natural sorbent material. Int. J. Environ. Sci. Technol. 2009, 6, 77-90. [CrossRef]

40. Abild-Pedersen, F.; Greeley, J.; Studt, F.; Rossmeisl, J.; Munter, T.R.; Moses, P.G.; Nørskov, J.K. Scaling properties of adsorption energies for hydrogen-containing molecules on transition-metal surfaces. Phys. Rev. Lett. 2007, 99, 4-7. [CrossRef]

41. Benjamin, M.M.; Leckie, J.O. Competitive adsorption of $\mathrm{Cd}, \mathrm{Cu}, \mathrm{Zn}$, and $\mathrm{Pb}$ on amorphous iron oxyhydroxide. J. Colloid Interface Sci. 1981, 83, 410-419. [CrossRef]

42. Sanderson, R.T. Chemical Bonds and Bond Energy; Academic Press: New York, NY, USA, 1976, ISBN 0-12-618060-1.

43. Yuan, J.-H.; Xu, R.-K. The amelioration effects of low-temperature biochar generated from nine crop residues on an acidic ultisol. Soil Use Manag. 2011, 27, 110-115. [CrossRef]

44. Enders, A.; Hanley, K.; Whitman, T.; Joseph, S.; Lehmann, J. Characterization of biochars to evaluate recalcitrance and agronomic performance. Bioresour. Technol. 2012, 114, 644-653. [CrossRef]

45. Herath, H.M.S.K.; Camps-Arbestain, M.; Hedley, M. Effect of biochar on soil physical properties in two contrasting soils: An Alfisol and an Andisol. Geoderma 2013, 209-210, 188-197. [CrossRef]

46. American Public Health Association (APHA). Standard Methods for the Examination of Water and Wastewater, 19th ed.; APHA: Washington, DC, USA, 1995.

47. Ra, J.S.; Jeong, T.Y.; Lee, S.H.; Kim, S.D. Application of toxicity identification evaluation procedure to toxic industrial effluent in South Korea. Chemosphere 2016, 143, 71-77. [CrossRef]

48. Rodda, N.; Carden, K.; Armitage, N.; Du Plessis, H.M. Guidelines for Sustainable Use of Greywater in Small-Scale Agriculture and Gardens in South Africa; Water Research Commission: Pretoria, South Africa, 2010.

49. Khodaverdiloo, H.; Samadi, A. Batch equilibrium study on sorption, desorption and immobilization of cadmium in some semi-arid zone soils as affected by soil properties. Soil Res. 2011, 49, 444-454. [CrossRef]

50. Desta, M.B. Batch sorption experiments: Langmuir and Freundlich isotherm studies for the adsorption of textile metal ions onto Teff straw (Eragrostis tef) agricultural waste. J. Thermodyn. 2013, 2013, 375830. [CrossRef]

51. Kumar, S.; Loganathan, V.A.; Ram, B.; Gupta, R.B.; Barnett, M.O. An Assessment of U (VI) removal from groundwater using biochar produced from hydrothermal carbonization. J. Environ. Manag. 2011, 92, 2504-2512. [CrossRef] [PubMed]

52. Gray, C.W.; McLaren, R.G.; Roberts, A.H.C.; Condron, L.M. Solubility, sorption and desorption of native and added cadmium in relation to properties of soils in New Zealand. Eur. J. Soil Sci. 1999, 50, 127-137. [CrossRef]

(C) 2019 by the authors. Licensee MDPI, Basel, Switzerland. This article is an open access article distributed under the terms and conditions of the Creative Commons Attribution (CC BY) license (http://creativecommons.org/licenses/by/4.0/). 